\title{
Using reclaimed water in dual pressurized water distribution networks.
}

\section{Cost Analysis}

\author{
Pardo, M.A. ${ }^{\text {a* }}$ Pérez-Montes, A. ${ }^{a}$ and Moya-Llamas, M.J. ${ }^{a}$ \\ ${ }^{a}$ Department of Civil Engineering, University of Alicante, Alicante, Spain. mpardo@ua.es
}

\begin{abstract}
Reclaimed water can be used for non-potable applications to reduce water consumption from freshwater sources. In several regions, the full potential of reusing treated wastewater has not yet been exploited. Establishing a circular economy could promote the acceptance of reclaimed water as an alternative water supply source. This study investigates the feasibility of constructing a treatment plant to supply reclaimed water for non-potable applications using a dual water distribution network, from an engineering cost standpoint.
\end{abstract}

\section{KEYWORDS}

Reclaimed water use, circular economy, cost analysis, dual water pressurized network

\section{INTRODUCTION}

In 2014, the total global water consumption was 4 trillion $\mathrm{m}^{3}$ (IEAIE, 2016). This figure has further increased by around 1\% in recent years (UN, 2019). Water withdrawals are expected to rise by $70 \%$ over the next $25 \mathrm{y}$ due to increased food production (Alexandratos et al., 2012). Water scarcity is aggravated by population growth (from 7.7 billion people in 2017 to $9.4-10.2$ billion people by 2050 (UN, 2019)), which is expected to increase by 2-3 billion people over the next 40 y (UNESCO-WWAP, 2012). Global water consumption is predicted to 
25 increase at an identical rate until 2050 to nearly $20 \%-30 \%$ above the current global water 26 consumption (Burek et al., 2016; UN, 2019).

27 Agriculture accounts for $70 \%$ of total water consumption (Siebert et al., 2010; Wada et 28 al., 2012). In 2012, 79\% of water in Spain was used for agriculture and the rest was used for 29 urban consumption, which corresponds to volumes of $15833 \mathrm{hm}^{3}$ and $4324 \mathrm{hm}^{3}$, respectively 30 (Olcina Cantos et al., 2018). Consequently, the reuse of water for agricultural irrigation is an 31 urgent requirement and promises significant water savings. Several regions around the world 32 are experiencing growing water shortages (Winpenny et al., 2010) and consequently, reclaimed 33 water can be used for non-potable applications to reduce freshwater demands. Although 34 reclaimed water offers enormous potential for irrigation, there are numerous concerns related 35 to agricultural sustainability and human health (Hamilton et al., 2005). In 2006, the total 36 amount of reused wastewater in Spain was between $368 \mathrm{hm}^{3} / \mathrm{y}$ and $450 \mathrm{hm}^{3} / \mathrm{y}$ (around $10.8 \%$ 37 and $13 \%$ of the total treated wastewater, respectively) (Jodar-Abellan et al., 2019b). The 38 "Asociación Española de Abastecimientos" (AEAS) estimated that the annual volume of reused 39 wastewater was $268 \mathrm{hm}^{3} / \mathrm{y}$ (AEAS, 2017) and the "Instituto Nacional de Estadística"' (INE) 40 stated that the annual volume of reused wastewater was $493 \mathrm{hm}^{3} / \mathrm{y}$ (INE, 2018). The province 41 of Alicante recycled about $42 \%$ of its wastewater in 2016 (59.1 hm ${ }^{3}$ out of $139.5 \mathrm{hm}^{3}$ ), and 42 discharged the remaining wastewater into the sea after purification (Jodar-Abellan et al., 43 2019a). Therefore, significant improvements are required to better utilise wastewater. In 44 Alicante city, $70 \%$ of the reclaimed water was from green urban areas, a volume of $1.2 \mathrm{hm}^{3} \mathrm{in}$ 452018 (Olcina Cantos et al., 2018) 
Recycled water is a constant and reliable water source and reduces the amount of water

49 extracted from the environment, while reducing conveyance costs. Moreover, the

50 treatment procedures required for non-potable water for use in urban areas are few. This

51 water can be used by urban residents for outdoor irrigation, non-residential toilet flushing, and

52 washing cars, houses, and decks. Other uses include industrial processes, water-based cooling

53 in manufacturing, and dust control at construction sites.

$54 \quad$ Some researchers have analysed the limits of the water quality of reused wastewater

55 (Müller and Cornel, 2017; Voulvoulis, 2018), the impact of the quality of the recycled water

56 (presence of pathogens, salinity, and chemical contaminants), both on the crop itself and on the

57 end users of the crops (Toze, 2006), and the occurrence of certain organic trace compounds

58 such as antibiotic residues in the reclaimed water (Hong et al., 2013). Others have analysed the

59 benefits and risks associated with reclaimed water irrigation (Chen et al., 2013; Deng et al.,

60 2019) and surveyed the opinions of farmers (Carr et al., 2011; Petousi et al., 2015) and

61 suburban residents (Chen et al., 2015; Ravishankar et al., 2018). The recent Regulation (EU)

62 2020/741 of the European Parliament and the Council of 25 May 2020 on minimum

63 requirements for water reuse (EU, 2020) considers these quality risks, establishes water

64 quality requirements, and recommends suitable measures for water reuse risk management

65 plans to protect the environment and human and animal health.

66 Favourable pricing (compared to potable water) and public information campaigns

67 (highlighting the environmental benefits) are market mechanisms to encourage the adoption

68 of reclaimed water (Metcalf et al., 2007). In China, nearly one-third of reclaimed water is used

69 for agricultural irrigation (Wang et al., 2017). Another possible application of reclaimed 70 municipal wastewater is groundwater recharging (Asano and Cotruvo, 2004; Sheng, 2005). 
Using reclaimed water involves building a secondary network (dual network) to supply

72 non-potable water to more customers. Such systems already exist in cities such as Hong Kong,

73 wherein a seawater system has been implemented for toilet flushing (Tang et al., 2006),

74 Singapore (Lee and Tan, 2016), and some cities in the USA (Barker et al., 2016). Some

75 researchers have simulated hydraulics in a freshwater pressurised network and a dual

76 distribution system (Kandiah et al., 2016), while others have examined the energy consumption

77 of dual potable and reclaimed water systems (Barker et al., 2016).

78 In previous research, the monetary aspects of wastewater recycling have been evaluated

79 (Chhipi-Shrestha et al., 2019), including the expenditure required for pipe and pump

80 installation, operational expenses, and environmental expenses (Kang and Lansey, 2012). Some

81 studies have used a cost-benefit analysis (Alcon et al., 2013) that evaluates the differences

82 between the investment costs (handled in the present time) and the future operational

83 expenses. Proper application of wastewater reuse projects and the incorporation of external

84 benefits can increase their feasibility (Molinos-Senante et al., 2011). The monetary usefulness

85 of water-reuse projects must consider the economic and environmental benefits, resource

86 availability, and the intangible benefits (environmental enhancements, community health, and

87 groundwater recharge and pollution) (Fan et al., 2015).

$88 \quad$ Farmers usually buy reclaimed water at low prices. To motivate water utility managers

89 to increase the adoption of reused water, the environmental costs associated with the

90 extraction of water must be adjusted in the form of taxes, based on the volume of freshwater

91 used instead of reclaimed water $\left(E U R / \mathrm{m}^{3}\right)$. The environmental costs $C_{E N V}\left(E U R / \mathrm{m}^{3}\right)$ in Europe

92 range from $0.84 \mathrm{EUR} / \mathrm{m}^{3}$ to $0 \mathrm{EUR} / \mathrm{m}^{3}$ in Denmark and Spain, respectively (Pardo and Valdes-

93 Abellan, 2018). 
In this study we aim to establish a procedure to measure the monetary cost that must be

95 paid by end-users when utility managers do not use recycled water. To accomplish this, a

96 wastewater treatment system and a pressurised dual network must be built in a district

97 metered area (DMA). The reclaimed water can be used to irrigate urban gardens to obtain water

98 (and economic) savings in the future, which are used to determine the payback period. To

99 further promote water saving, the environmental impact of extracting water from the natural

100 environment is considered, and the effect of the environmental cost on the payback period is

101 analysed. The environmental cost of water can promote the establishment of wastewater reuse

102 projects for irrigation. This study considers a real DMA in a municipality in Alicante Province

103 (Spain).

104 The rest of the manuscript is organised as follows: Section 2.1 discusses the differences

105 between the current scenario (laissez-faire scenario) and the scenario with a wastewater

106 treatment plant and dual network; the wastewater quality is analysed in Section 2.2; the

107 purification treatment process in a real district metered area (DMA) is discussed in Section 2.3;

108 a monetary analysis is presented in Section 2.4; Section 3 presents the calculations; Section 4.1

109 describes the actual water pressurised network (WPN) of the proposed system; the

110 construction of a wastewater treatment facility is described in Section 4.2; the reclaimed water

111 delivery system is presented in Section 4.3; the cost data are displayed in Section 4.4; finally,

112 the results are presented in Section 5 along with a step-by-step evaluation, and the conclusions

113 are presented in Section 6.

114

115 2. MATERIAL AND METHODS

116 


\subsection{Features of the current and future scenarios (WPN and dual} network) water to consumers. The water audit for this WPN is:

$\forall_{\text {inj }}=\forall_{\text {cons }}+\forall_{\text {irr }}+\forall_{\text {leaks }}$

where, $\forall_{\text {inj }}$ the volume injected into the WPN, $\forall_{\text {cons }}$ is the volume consumed by residential users, $\forall_{\text {irr }}$ is the volume used for the irrigation of urban gardens, and $\forall_{\text {leaks }}$ is the 124 volume lost through leakage. The DMA considered herein incorporates a wastewater network that gathers sewage and transports it to the wastewater treatment plant (WWTP). The volume of treated wastewater is assumed to be $C r . \forall_{\text {cons }}$ (where $C r$ is the return factor equal to the ratio of wastewater flow to water consumption).

In the proposed scenario, two water distribution networks exist: the first (the existing one) which supplies freshwater for purposes other than irrigation (Eq. 2), and the second which supplies reclaimed water for irrigation (Eq. 3). The water audit of the existing network follows and $\forall_{i r r-D}^{*}$ represent the volume used for the irrigation of urban gardens and other crops, and $\forall_{\text {leaks_D }}$ represents the volume lost through leakage in the dual WPN. The wastewater network in the proposed scenario transports sewage to the treatment area (not to the WWTP). Notably, the amount of water consumed by the end-users is the same in both scenarios, which implies that the cost of freshwater does not affect the analysis herein. 


\subsection{Wastewater reclamation and reuse: permitted uses for reclaimed} water

Reclaimed water is wastewater that, after undergoing treatment, can be used for various purposes, based on the minimum water quality required for each use. The approval of water quality levels based on usage and treatment processes are stipulated by the European regulations on the reuse of wastewater (EU 2020) and the Spanish regulations on the reuse of wastewater (BOE, 2007), which establishes the legal requirements for the reuse of treated water. These regulations offer a normative framework for new water supply sources that are capable of providing additional water resources. This ensures the release of high-quality water resources for more demanding uses such as public supply, reduces pollutant discharge to natural watercourses (Scott et al., 2004), aids the recovery of nutrients in wastewater through the utilisation of regenerated water for agricultural and gardening irrigation (Jiménez et al., 2010; Vergine et al., 2017), and guarantees long-term water supply. irrigation, toilet flushing, washing cars and/or houses), irrigation (municipality consumption in urban green areas), and industrial uses (cooling of manufacturing and industrial processes, 158 and dust control at construction sites). Each use has different quality requirements. regeneration of the effluent. It must specify:

- $\quad$ Treated water flowrates.

- Qualities demanded in the reclaimed effluent corresponding to the following limits: Escherichia coli (UFC/100 ml), nematode eggs (unit/10 litres), suspended solids (mg/L), and turbidity (NTU) 
- Regeneration procedure

- $\quad$ Storage and delivery structures five days $\left(\mathrm{BOD}_{5}\right)$ and chemical oxygen demand (COD)) and suspended solids (SS). Additionally, where necessary, nutrients such as nitrogen $(\mathrm{N})$ and phosphorus $(\mathrm{P})$ must be reduced as well.

171 Table 1 shows the quality requirements for different water uses: (a) domestic wastewater, (b)

172 industrial, livestock, commercial, or service wastewater, (c) rainwater, and (d) clean water that infiltrates the network of collectors from aquifers and other uncontrolled inputs such as streams and public fountains.

Table 1. Quality groups based on established bacteriological limits in R.D. 1620/2007 for

\begin{tabular}{|c|c|c|c|c|}
\hline \multicolumn{5}{|c|}{ different water uses } \\
\hline \multicolumn{2}{|l|}{ USES } & $\begin{array}{l}\text { ESCHERICHIA COLI } \\
\text { UFC } / 100 \mathrm{mI}\end{array}$ & $\begin{array}{l}\text { INTESTINAL } \\
\text { NEMATODES }\end{array}$ & $\begin{array}{l}\text { LEGIONELLA } \\
\text { UFC/100mI }\end{array}$ \\
\hline Industrial a) & $\begin{array}{l}\text { Cooling towers, evaporative } \\
\text { condensers }\end{array}$ & absence & absence & absence \\
\hline Urban a) and b) & $\begin{array}{l}\text { Private irrigation and toilet- } \\
\text { flushing }\end{array}$ & absence & $<1$ & $<100$ \\
\hline Environmental a) & Direct aquifer discharge & absence & $<1$ & Not defined \\
\hline $\begin{array}{l}\text { Urban a), b) c) and } \\
\text { d) }\end{array}$ & $\begin{array}{l}\text { Urban services, firefighting, } \\
\text { and car-washing systems }\end{array}$ & $<100-200$ & $<1$ & $<100$ \\
\hline $\begin{array}{l}\text { Agricultural a) } \\
\text { and recreative a) }\end{array}$ & $\begin{array}{l}\text { Unrestricted agricultural } \\
\text { irrigation, golf course } \\
\text { irrigation }\end{array}$ & & & \\
\hline $\begin{array}{l}\text { Agricultural a),b) } \\
\text { and c) }\end{array}$ & $\begin{array}{l}\text { Irrigation of agricultural } \\
\text { products for non-fresh human } \\
\text { consumption, watering of }\end{array}$ & $<1000$ & $<1$ & Not defined \\
\hline
\end{tabular}




\begin{tabular}{|l|l|l|l|l|}
\hline & $\begin{array}{l}\text { pastures for animals, } \\
\text { aquaculture }\end{array}$ & & & \\
\hline Industrial & $\begin{array}{l}\text { Processing and cleaning water } \\
\text { for the food industry }\end{array}$ & & & $<100$ \\
\hline environmental & $\begin{array}{l}\text { Aquifer recharge by } \\
\text { percolation }\end{array}$ & $<1000$ & No limits & No limits \\
\hline
\end{tabular}

178

179

A corresponding study of water quality must be carried out based on the population to whom the water is to be supplied. The water quality is determined by the corresponding requirements of the corresponding treatment facilities. The size of the population can be determined based on the number of inhabitants and/or the pollution load, and classified into small, medium, and large populations. The European Union considers small agglomerations to be those with a population of less than 2000 inhabitant equivalents.

An inhabitant equivalent transfers pollutants that have a biodegradable organic load with a 5-day biochemical oxygen demand $\left(\mathrm{BOD}_{5}\right)$ of $60 \mathrm{~g}$ of oxygen per day $(1$ inhabitant equivalent generates approximately $100 \mathrm{l} / \mathrm{d}$ of urban wastewater).

Therefore, according to Directive 91/271/EEC, 1991, 12, a small population of 200 inhabitants can determine the water quality requirements. The purpose of this Directive is the collection, treatment, and discharge of urban wastewater and the treatment and discharge of water from certain industrial sectors. Thus, the percentage reduction of each of the wastewater parameters is $\mathrm{BOD}_{5}=70 \%-90 \%, \mathrm{COD}=75 \%$, and $\mathrm{SS}=70 \%$.

\subsection{Wastewater treatment}


The wastewater treatment system presented herein is for a wastewater volume of $\operatorname{Cr} . \forall_{\text {cons }}$, as stated previously. The purification process is divided into three stages: pre197 treatment, primary treatment, and secondary or biological treatment.

The proper execution of the pre-treatment and primary treatment operations is vital for

199 the other components of the treatment plant (Ortega de Miguel et al., 2010). This strategy may 200 be implemented for the wastewater received from small municipalities or DMAs. The pre201 treatment stage can include roughing, de-sanding, and degreasing elements, while the primary 202 treatment can be performed in septic or Imhoff tanks, or by decantation.

203 Secondary treatment of wastewater from small communities can combine intensive 204 technologies such as extended aeration systems (AS), fixed-bed bacteria cultures, trickling 205 filters (TF), rotating biological contactors (RBC), sequential batch reactors (SBR), and moving 206 bed biofilm reactors (MBBR) (Matamoros et al., 2016). This study does not focus on specific 207 technologies but rather on the mechanism needed to obtain the required quality of reclaimed 208 effluents for irrigation (Table 1) according to the stipulated limits: Escherichia coli $<100-200$ 209 UFC/100 ml; Nematode eggs < 1 unit/10 l; and Legionella < 100 UFC/100 ml. Additional 210 demands such as COD $=125 \mathrm{mg} / \mathrm{l}, \mathrm{BOD}_{5}=25 \mathrm{mg} / \mathrm{l}, \mathrm{SS}<35 \mathrm{mg} / \mathrm{l}, \mathrm{N}<15 \mathrm{mg} / \mathrm{l}$, and $\mathrm{P}<2 \mathrm{mg} / \mathrm{l}$, 211 must be satisfied as well.

\subsection{Economic analysis of alternatives}

The benefits of installing a treatment plant and a dual network to deliver reclaimed water

215 for irrigation are analysed herein. Considering the cost framework (Cabrera et al., 2013), the

216 fixed costs (construction, asset amortisation, etc.) and social costs are equal in both cases. The 217 variable cost of water depends on the resource itself, the energy required, and the lifespan of 218 the infrastructure. The operation and maintenance costs of the infrastructure (energy cost 
219 linked to pumping, treatment, and transport, which is analogous to the amount of water 220 treated) in the scenarios compared herein are different, and their effect on the environmental 221 costs (as a tax to encourage utility managers to use the proposed system) are assessed 222 accordingly. The environmental costs associated with energy (greenhouse gas emissions, 223 carbon credits, and $\mathrm{CO}_{2}$ emissions) are not considered herein.

224 In addition to the cost of the equipment that must be purchased initially, the total cost of 225 the dual network infrastructure (civil work, piped irrigation network, land, and asphalt), 226 electrical devices, removal of vegetation, health and safety of the workers while laying the new 227 pipelines, solid waste handling and individual safety material, indirect costs, and taxes must be 228 considered while evaluating the feasibility of constructing a treatment plant and dual 229 pressurised network. In addition, the wastewater treatment plant, which consists of structures 230 for pre-treatment, primary treatment, and secondary treatment, a tank for storing the 231 reclaimed water, pipelines, and measurement, control, and monitoring devices, must be 232 constructed as well.

The proposed system provides monetary savings on account of lower freshwater 234 consumption and lesser wastewater treatment in the WWTP (an aggregate cost). For 235 comparison, the costs are presented in current financial units using the equivalent continuous 236 discount rate $r$ (Kleiner and Rajani, 2001). The objective function is the net present value (NPV), 237 which considers the current investments $\left(t_{p}\right)$ and the future earnings after a time $t$. consumed by the WPN in case $0 ; E_{1}^{*}$ and $E_{d}$ are the energy consumed by the WPN and the dual network, respectively; $I_{0}$ is the purchase achieved in year zero; and $S_{i}$ is the economic savings. 
243 The cost of water reclaimed $\left(C_{W R}\right)$, the environmental cost $\left(C_{E N V}\right)$, and the sanitation costs $\left(C_{S}\right)$,

244 must be calculated, along with the volume used for the irrigation of urban gardens and other

$245 \operatorname{crops}\left(\forall_{i r r} ; \forall_{i r r-D}^{*}\right)$, the volume injected into the WPN (case 0$) \forall_{i n j}$, the volume injected into

246 the WPN (future case) $\forall_{i n j}^{*}$, and the water treated in the wastewater treatment plant $C r . \forall_{\text {cons }}$.

247 The extra maintenance is incorporated with the value $C_{m}^{*}$. These figures are equivalent to the

248 pump energy consumption $\left(\mathrm{E}_{P}\right)$. Equating the derivative of Eq. 4 to zero, the payback period can

249 be calculated as:

250

$$
T_{i}=\frac{-1}{r} \cdot \ln \left(1-\frac{r \cdot I_{o}}{S_{i}}\right)
$$

251 where, $T_{i}$ (in years) is the payback period. The smaller the value of this criterion, the greater

252 the energy savings per monetary unit devoted to the purchasing apparatus. Based on these

253 numbers, the environmental costs to compensate for the investment in $t_{r}^{*}$ years, is:

$$
C_{E N V}=\frac{1}{\forall_{i n j}}\left[\begin{array}{c}
\left(\frac{r . I_{O}}{1-e^{-r t_{r}^{*}}}\right)+C_{m}^{*}-C_{W} *\left(\forall_{i n j}-\forall_{i n j}^{*}\right)-C_{E N}\left(E_{1}-E_{1}^{*}-E_{d}\right)- \\
-C_{W R} *\left(\forall_{i r r}+\forall_{i r r-D}^{*}\right)-C_{S} * C r . \forall_{c o n s}
\end{array}\right]
$$

This represents the value that must be paid by the utility manager to compensate for the use of

256 freshwater for irrigation.

\section{CALCULATION PROCESS}

The process to calculate the environmental costs is described in this section here (Figure

1).

Step 1, Current case input data: This project requests having a calibrated water model

262 which reflects the current state of the WPN. The model must have no errors when running this

263 hydraulic simulation (frequent inaccuracies in models are negative pressures, separated

264 junctions/tanks/reservoirs). The user must know some more data as the return factor $\mathrm{Cr}$

265 (wastewater flow divided by water consumption). 
Step 2, Current case calculation: The water audit is calculated. The user may determine

267 the $\forall_{\text {inj }}$ the volume injected into the WPN, $\forall_{\text {cons }}$ the amount consumed by residential 268 purchasers and the $\forall_{i r r}$ the quantity used in irrigation of the urban garden. The volume wasted 269 through breaks $\left(\forall_{\text {leaks }}\right)$ is considered. If hydraulic software is EPAnet (Rossman, 2000), the 270 most widely used software for urban WPN, we may establish leakage by exploiting the UAleaks 271 software (Pardo and Riquelme, 2019). The energy taken by the WPN in case $0\left(E_{1}\right)$ is calculated 272 herein.

273 Step 3 Building the future case:

This project demands to create two calibrated water models describing a future state.

275 The first is like the preceding one (Case 0) excluding the volume handled in irrigation of the 276 urban garden $\left(\forall_{\text {irr }}=0\right)$; an amount delivered by the dual network. The dual pressurized 277 network delivers reclaimed water and the volume injected is corresponding to $\left(\forall_{\text {inj-D }}=C r *\right.$ $278 \forall_{\text {cons }}$ ). Both models must contain no errors and bring us successful hydraulic calculations (as 279 in step 1).

Step 4, Future case calculation: The water and energy audits of the two WPN built in 281 Step 3 is calculated to get the volume $\left(\forall_{i n j}^{*}, \forall_{i r r}\right.$ and $\left.\forall_{i r r-D}^{*}\right)$ and the energy consumed in WPN 282 (without considering freshwater to irrigation) $E_{1}^{*}$ and in the Dual network $E_{d}$. Step 5, Economic Input data: The economic input data required here are:

- $\quad r$, equivalent continuous discount rate $(-)$

- $\quad$ Energy costs $\left(C_{E N}=\mathrm{EUR} / \mathrm{Kwh}\right)$

- $I_{0}$ is the investment performed in year zero. This value includes every cost described before build a dual pressurized network and a treatment plant.

- $t_{r}^{*}$ (years), the number of years required to compensate for the investment. 
- $C_{W}$ Cost of freshwater in EUR/m³.

- $C_{W R}$ Cost of the reclaimed water in EUR/ $/ \mathrm{m}^{3}$.

- $C_{S}$ Sanitation costs in EUR/m³.

CURRENT CASE INPUT DATA

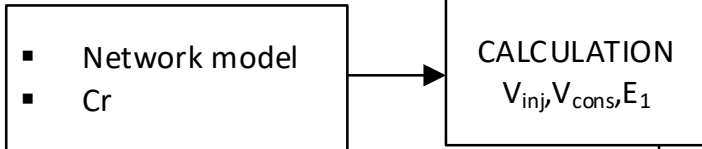

FUTURE CASE INPUT DATA

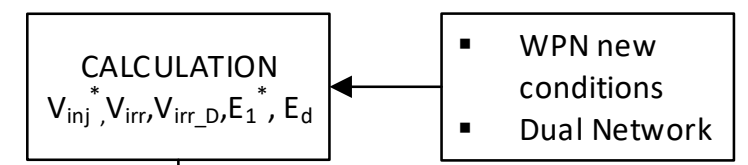

\section{STEP 5}

\section{ECONOMIC INPUT DATA}

- $I_{0}$, investment (EUR)

- $C_{E N}$, Energy costs (EUR/kWh)

- $r$ discount rate (\%)

- $\operatorname{Tr}^{*}$ (years)

- $C_{w}$ Cost of freshwater (EUR/ $\left./ \mathrm{m}^{3}\right)$

- $C_{W R}$ Cost of the reclaimed water (EUR/ $\mathrm{m}^{3}$ )

- $C_{S}$ Sanitation cost $\left(E U R / \mathrm{m}^{3}\right)$.

\section{CASE STUDY}

Figure 1. Flowchart of the calculation process

\section{STEP 6}
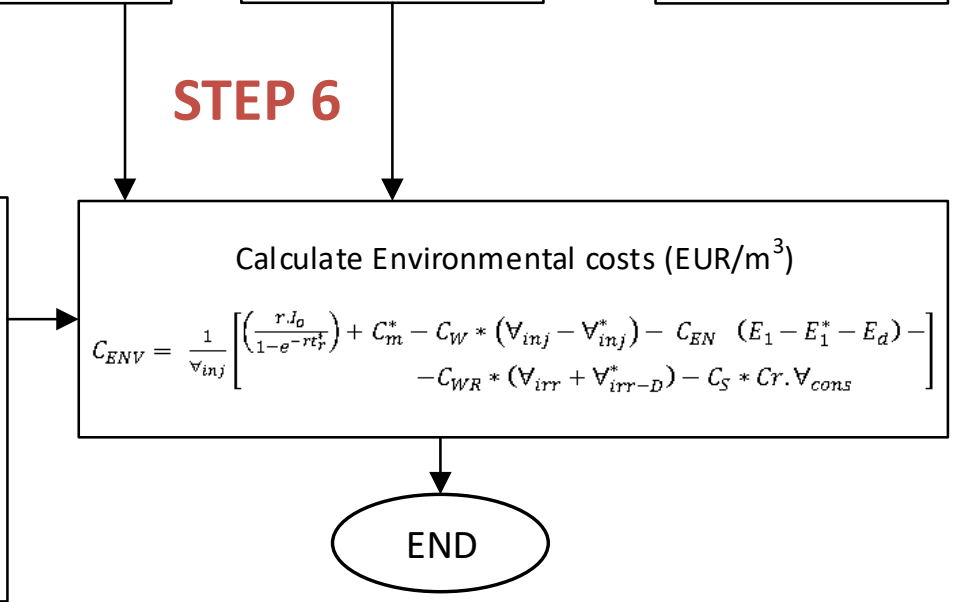

\subsection{WPN layout}

The network is designed with pipes with a nominal diameter of $100 \mathrm{~mm}$ (FD-C 100 NT-

304 HP BZN e6.1 JE. DN 100L6) and a thickness of $6 \mathrm{~mm}$. It is considered that there are 50 homes 
and 200 inhabitants in this area of a town located in Alicante province. The green area (Figure

306 2) corresponds to 0.21 hectares, taking into account the consumption of the flora of the location,

307 it will correspond to a different daily consumption, Tree: $10.5 \mathrm{l} /$ day; grass, $7 \mathrm{l} / \mathrm{m}^{2}$ and palm tree: $1.8 \mathrm{l} / \mathrm{m}^{2}$. Water supplied comes from a reservoir (elevation $43.34 \mathrm{~m}$ ) and by

309 pumping device (CR 64-1-1A-F-A-E-HQQE; Grundfos). The return factor (wastewater flow 310 divided by water consumption) is $\mathrm{Cr}=0.8$.

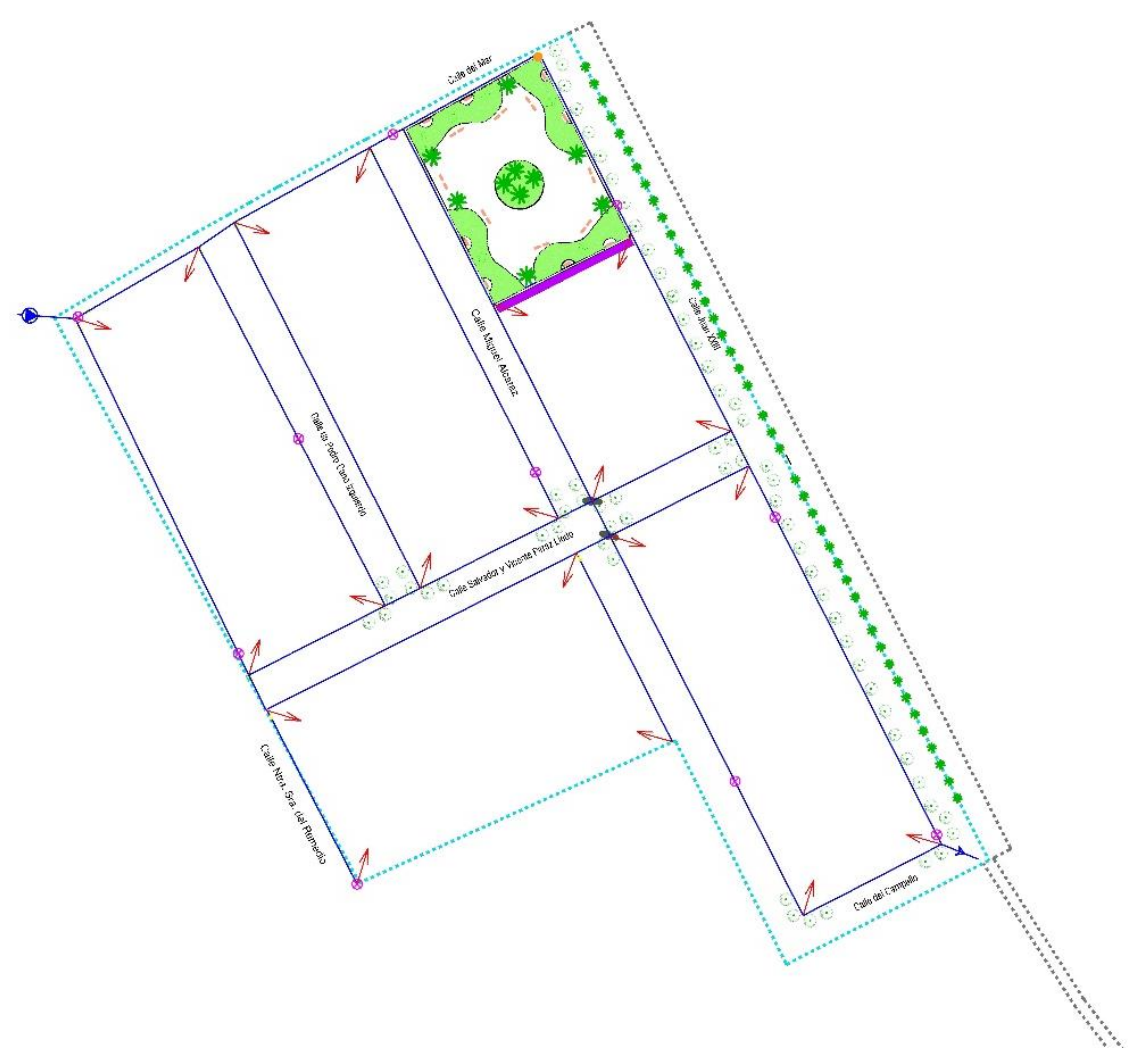

\section{$314 \quad$ 4.2. Wastewater treatment}

Figure 2. The general layout of the network.

The process followed to recycle water is described here. We take common urban wastewater (Ortega de Miguel et al., 2010) (Table 2). 
Table 2 Typical composition of wastewater effluent.

\begin{tabular}{cc}
\hline Parameter & Wastewater effluent (mg/l) \\
\hline Suspended soils & 250 \\
BOD $_{5}$ & 300 \\
$\mathrm{COD}$ & 600 \\
$\mathrm{~N}-\mathrm{NH}_{4}{ }^{+}$ & 30 \\
$\mathrm{~N}$ & 50 \\
$\mathrm{P}$ & 10 \\
Faecal coliforms & $10^{7}$ \\
\hline
\end{tabular}

\subsubsection{Pretreatment}

The structure includes a structure of grids (inclined steel bars) spaced across the conveying through which the wastewater moves. We refer the grates used here are rough and 322 fine sediments. The difference between the two is the removal of material dealing with its size. 323 The wastewater velocity must avoid waste and sand deposition.

Inhoff Tanks offer anaerobic stabilization of the sludge. The maximum design capacity of Imhoff tanks ranges below a population of 1000 equivalent inhabitants.

\subsubsection{Primary treatment}

We use Imhoff Tanks for the primary treatment of wastewater generated in individual residences and small population facilities which lack nearby sewage networks. Besides, the

333 attaches pathogens to a carrier media, which rotates semi-immersed (40\% of its surface area) 334 in the wastewater. These practices describe a specialized choice to the conventional Active 335 Sludge process (Cortez et al., 2008). In recent years, RBCs have been exploited to treat various 336 types of wastewater, including urban wastewater (Akunna and Jefferies, 2000; Grady Jr, 1982; 
337 Nowak, 2000). By turning slowly (1-2 rpm), it exposes its surface to water and air. A film of 338 bacterial biomass develops on the surface, using the soluble organic matter present in the 339 wastewater as a substrate and getting in the oxygen indispensable for respiration from the 340 atmospheric air during the state when the surface is out of the water (Scholz, 2006).

341

\section{4.3. Dual pressurized network}

343 Once the wastewater treatment process has been completed, the reclaimed water is 344 stored in a tank for later use. Irrigation occurs twice per day (every 12 hours) to decrease tank 345 size. The green areas of the case study are irrigated first, and the surplus volume will be used 346 for watering the surrounding green areas. We design the irrigation network with 700m of pipes 347 with a nominal diameter of 100 mm (pipe FD-C 100 NT-HP BZN e6.1 JE. DN 100L6) and a 348 thickness of $6 \mathrm{~mm}$. The pump is (CR 64-1-1A-F-A-E-HQQE; Grundfos). The green area irrigated 349 corresponds to 0.21 hectares Figure 3. 


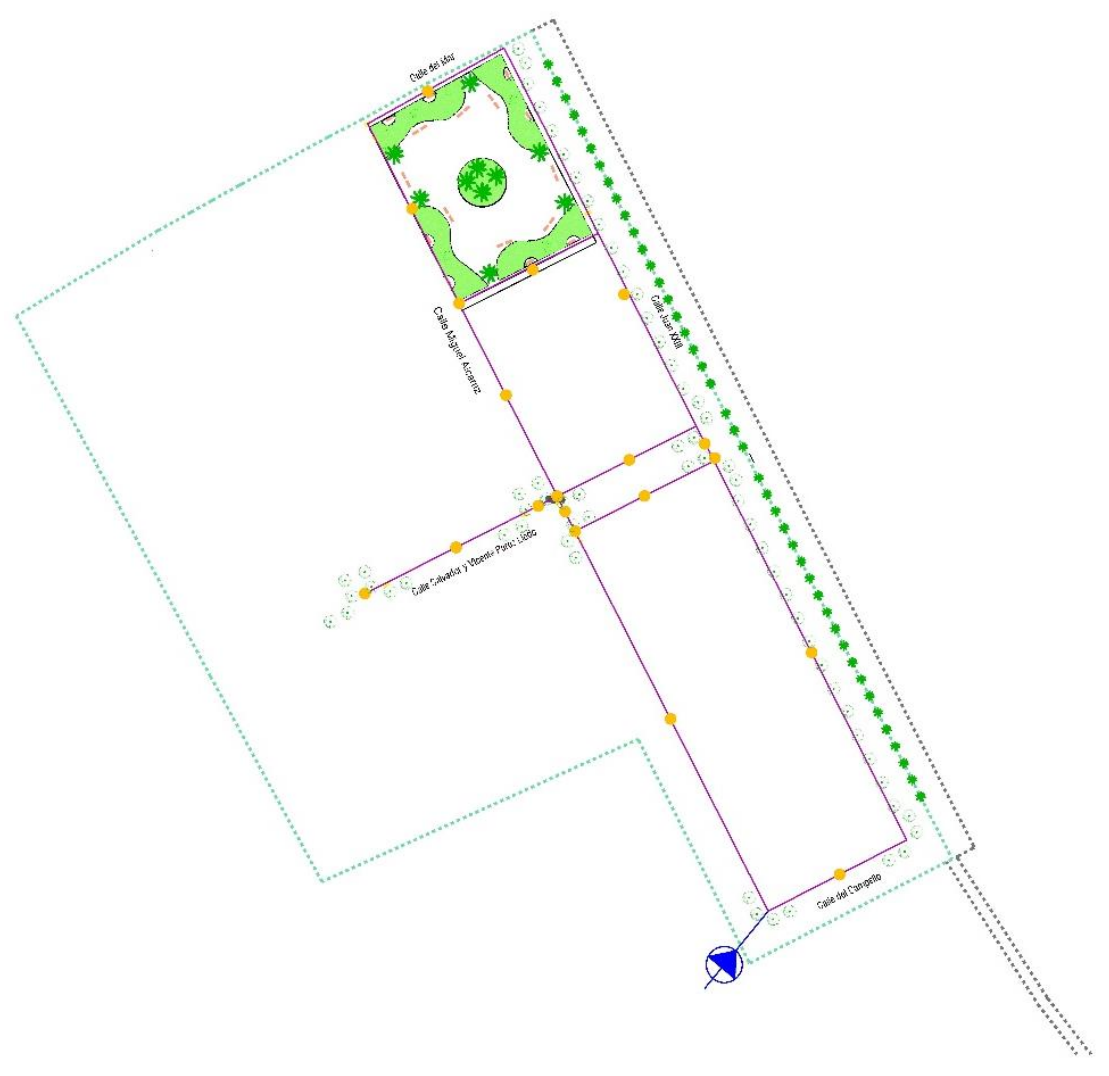

\section{4.4. Cost data}

Figure 3. Layout Dual network

The investment required for the wastewater treatment and dual network involves civil work, pipes irrigation network, wastewater regeneration, land and asphalt, demolitions, 356 collective protection, individual protection equipment, indirect costs and taxes, resulting in a 357 quantity of $I_{0}=624970.52$ EUR. $C_{m}^{*}=11780 \mathrm{EUR} / \mathrm{y}$ 


\begin{tabular}{|c|c|c|c|c|}
\hline Treatment & Operation & Costs & Frequency & Annual costs \\
\hline \multirow{3}{*}{ Pre } & Cleaning pre-treatment system & $16(\mathrm{EUR} / \mathrm{h})$ & Twice/week & 416 \\
\hline & Inspection and measurement & $16(\mathrm{EUR} / \mathrm{h})$ & Twice/year & 32 \\
\hline & Sludge removal & $15\left(\mathrm{EUR} / \mathrm{m}^{3}\right)$ & Twice/year & 2250 \\
\hline Primary & Sludge removal & $15\left(\mathrm{EUR} / \mathrm{m}^{3}\right)$ & Once/week & 8250 \\
\hline Secondary & Checking rotation and purge decanter & $16(\mathrm{EUR} / \mathrm{h})$ & Three times/week & 832 \\
\hline
\end{tabular}
reclaimed water $C_{W}=1.22 \mathrm{EUR} / \mathrm{m}^{3}$ (García-Rubio et al., 2015), the cost of the reclaimed water $C_{W R}=0.015 \mathrm{EUR} / \mathrm{m}^{3}$ (Mas Ortega, 2016), $\mathrm{r}=2 \%$ equivalent continuous discount rate, energy costs, $C_{E N}=0.1 \mathrm{EUR} / \mathrm{Kwh}$, number of years required to compensate the investment, $t_{r}^{*}=5 \mathrm{y}$.

\section{RESULTS AND DISCUSSION}

\begin{tabular}{l|c|cc}
\hline & Current State & \multicolumn{2}{|c}{ Future state } \\
\hline & WPN & WPN* & Dual Network \\
\hline$\forall_{\text {inj }}$ Injected water $\left(\mathrm{m}^{3}\right)$ & 129.68 & 129.15 & 103.32 \\
$\forall_{\text {cons }}$ Consumed water $\left(\mathrm{m}^{3}\right)$ & 129.15 & 129.15 & - \\
$\forall_{\text {irr }}$ Volume irrigation $\left(\mathrm{m}^{3}\right)$ & 0.5263 & & 0.53 \\
$\forall_{\text {irr }-D}^{*}$ Volume irrigation other crops $\left(\mathrm{m}^{3}\right)$ & - & - & 102.80
\end{tabular}




\subsection{Reclaimed water}

In Table 5, we show the quality values got after the treatment process. We may see that the final effluent values are lower than the concentration allowed.

381 Table 5. Pollutants concentration of the effluent

\begin{tabular}{|c|c|c|c|c|c|}
\hline & Inhoff tank & & & $\mathrm{RBC}$ & \\
\hline Param. & \% Reduction & $\begin{array}{l}\text { Final eff. (mg/l) } \\
\left.\text { (T.1 }{ }^{\circ}\right)\end{array}$ & \% Reduction & $\begin{array}{l}\left.\text { Final eff. (T.2 }{ }^{\circ}\right) \\
(\mathrm{mg} / \mathrm{L})\end{array}$ & $\begin{array}{ll}\text { Max. } & \text { Conc. } \\
(\mathrm{mg} / \mathrm{L}) & \end{array}$ \\
\hline COD & - & 184.132 & $70-90$ & 55.239 & $125 \mathrm{mg} / \mathrm{L} \mathrm{O}_{2}$ \\
\hline $\mathrm{BOD}_{5}$ & $30-65$ & 64.446 & $80-98$ & 12.889 & $25 \mathrm{mg} / \mathrm{L} \mathrm{O}_{2}$ \\
\hline SS & $35-85$ & 68.386 & $75-98$ & 17.096 & $35 \mathrm{mg} / \mathrm{L}(\mathrm{d})$ \\
\hline $\mathrm{N}$ & $0-60$ & 13.153 & $30-80$ & 9.206 & $15 \mathrm{mg} / \mathrm{L}$ \\
\hline $\mathrm{P}$ & $0-75$ & 2.630 & $25-30$ & 1.927 & $2 \mathrm{mg} / \mathrm{L}$ \\
\hline
\end{tabular}

382

383

\subsection{Economic analysis}

384 Now that we know the investment ( $I_{0}=624970.52$ EUR), we must calculate the monthly savings

385 obtained. The monthly energy savings are:

386

$$
\left(C_{E N} x\left(E_{1}-E_{1}^{*}-E_{d}\right)\right)=0.1 \times(7.69-7.6588-5.634) \times 30=-16.80 \mathrm{EUR} / \mathrm{m}
$$

387 As this value is negative, it means that we consume more energy than before.

388 The monthly savings which come from saving freshwater is equal to:

389

$$
\left(C_{W} x\left(\forall_{i n j}-\forall_{i n j}^{*}\right)\right)=1.22 x(129.68+129.15) x 30=19.398 \mathrm{EUR} / \mathrm{m}
$$

390 The monthly savings which come from selling water reclaimed:

$$
\left(C_{W R} x\left(\forall_{i r r}+\forall_{i r r-D}^{*}\right)\right)=0.015 *(0.53+102.80) x 30=46.4985 E U R / m
$$

392 The sanitation cost savings are: 


$$
\left(C_{S} x \operatorname{Cr} x \forall_{\text {cons }}\right)=0.74 x(0.8 \times 129.15) \times 30=2293.704 \mathrm{EUR} / \mathrm{m}
$$

394 The operation costs (a value negative as maintenance costs are now higher) are:

$$
\left(-C_{m}^{*}\right)=\frac{11780}{12}=-981.66 \mathrm{EUR} / \mathrm{m}
$$

396 In short, we substitute the above-mentioned values in equation 4:

$$
\left[-624970.52+\int_{0}^{5 * 12}\left(1361.1+C_{E N V} * 129.68 * 30\right) x e^{-0.02 t / 12} d t\right]=0
$$

398 Being the $\left(1341.7+C_{E N V} x 129.68 \times 30\right)$ the monthly economic savings. Note that the interest 399 rate is $r=2 \%$ per year, and in this formula, we use $r=0.02 / 12$ as we want the monthly value. We 400 can solve this equation or equation (6)

401

$$
C_{E N V}=\frac{1}{129.68 * 30} x\left[\left(\frac{\frac{0.02}{12} * 624970.52}{1-e^{-0.02 * 5}}\right)-1361.1\right]=2.46 \mathrm{EUR} / \mathrm{m}^{3} .
$$




\subsection{Sensitivity analysis}

405 The calculations were reproduced for other payback periods, to obtain the following 406 values, Figure 4.

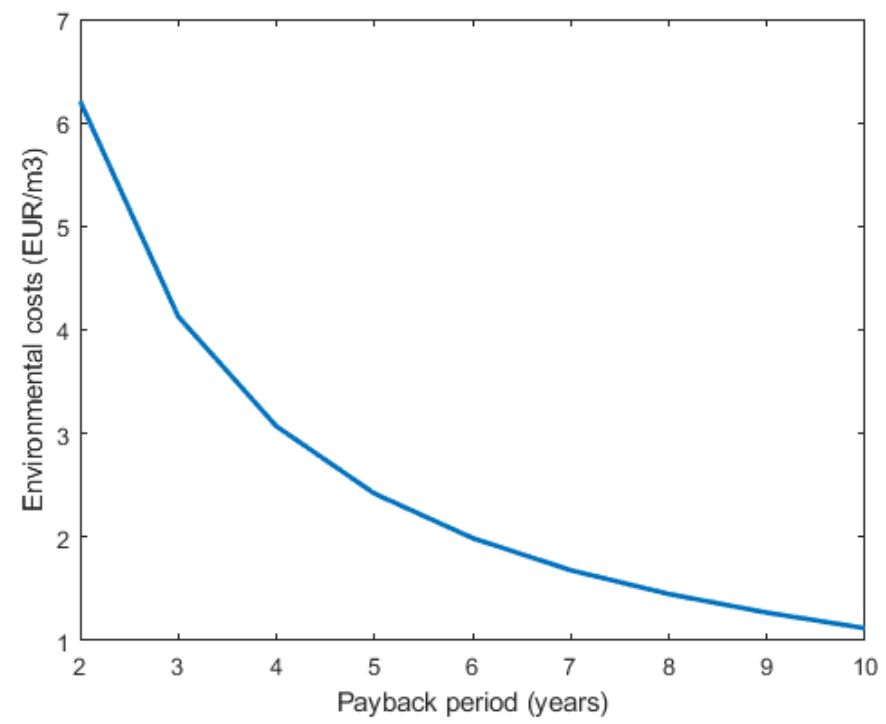

411 values of $r=2 \%, r=3 \%$, and $r=4 \%$.

412 Table 6 Environmental cost for different values of - equivalent continuous discount rate - $r$ and payback 413

\begin{tabular}{cccc|cccc}
\multicolumn{7}{c}{ period. } \\
\hline $\boldsymbol{T}$ & $\mathbf{r = 2 \%}$ & $\mathbf{r = 3 \%}$ & $\mathbf{r}=\mathbf{4 \%}$ & $\boldsymbol{T}$ & $\mathbf{r}=\mathbf{2 \%}$ & $\mathbf{r}=\mathbf{3 \%}$ & $\mathbf{r = 4 \%}$ \\
\hline 2 & 6.21 & 6.28 & 6.34 & 7 & 1.68 & 1.75 & 1.82 \\
3 & 4.13 & 4.20 & 4.26 & 8 & 1.45 & 1.52 & 1.59 \\
4 & 3.07 & 3.13 & 3.20 & 9 & 1.27 & 1.34 & 1.41 \\
5 & 2.46 & 2.49 & 2.56 & 10 & 1.12 & 1.19 & 1.27 \\
6 & 1.99 & 2.06 & 2.13 & & & & \\
\hline
\end{tabular}


The payback period for the environmental costs in Denmark $\left(C_{E N V}=0.84\right)$ and $r=2 \%$

416 are calculated below. The environmental savings are equal to $C_{E N V} x \forall_{i n j}=0.84 \times 129.68 \times 30=$

4173267.93 EUR. Therefore, the monthly savings are $(1341.7+3267.93=4609.63) E U R$

$$
T_{i}=\frac{-1}{r} \cdot \ln \left(1-\frac{r \cdot I_{o}}{S_{i}}\right)=\frac{-1}{0.02 / 12} \cdot \ln \left(1-\frac{\frac{0.02}{12} * 624970.52}{4690.63}\right)=153.68 m=12.8 y
$$

\section{CONCLUSIONS}

Reclaimed wastewater can be used for non-potable applications to reduce freshwater consumption. However, the potential of this water source has not yet been fully exploited (in Spain, only $10.8 \%-13 \%$ of the total sanitation water is reused). Owing to the prolonged water scarcity in Alicante, nearly $42 \%$ of sanitation water is reused. Agriculture has the largest demand for water and consumes almost $70 \%$ of all water. Therefore, there is an urgent need to encourage utility managers to promote the use of reclaimed water in irrigation. Furthermore,

427 a procedure to determine an environmental tax that must be paid by utility managers for not 428 using recycled water was established herein. This can reduce freshwater consumption and promote the use of reclaimed water in agriculture.

The results indicated that the proposed treatment plant is impractical now. This study 431 considered low prices for reclaimed water $\left(0.015 \mathrm{EUR} / \mathrm{m}^{3}\right)$ and symbolic benefits. 432 Consequently, due to the rising operating costs of the wastewater treatment plant and the small 433 population size of the case study, the proposed system cannot benefit from economies of scale. 434 Only the sanitation costs could be recovered due to consumer support. Thus, the proposed 435 approach is only suitable in areas with water scarcity that have significant water costs (water obtained from low aquifers or desalination plants). As only a small amount of freshwater is 
437 required to irrigate the urban areas in the case considered herein, the water savings are 438 negligible.

439 However, there is still a need to shift towards a modern water supply scheme that 440 promotes the establishment of such systems. The environmental tariff recommended herein for 441 using freshwater for irrigation can increase the feasibility of such projects.

442

443 7. REFERENCES

444 AEAS, 2017. Informe Sobre Aguas Residuales en España; Día Mundial del Agua (2017) 445

URL https://www.asoaeas.com/sites/default/files/Documentos/Informe sobre aguas residuales AEAS.pdf

Akunna, J.C., Jefferies, C., 2000. Performance of family-size sequencing batch reactor and rotating biological contactor units treating sewage at various operating conditions. Water Sci. Technol. 41, 97-104.

451 Alcon, F., Martin-Ortega, J., Pedrero, F., Alarcon, J.J., de Miguel, M.D., 2013. Incorporating 452 Non-market Benefits of Reclaimed Water into Cost-Benefit Analysis: A Case Study 453 of Irrigated Mandarin Crops in southern Spain. Water Resour. Manag. 454 https://doi.org/10.1007/s11269-012-0108-z

Alexandratos, N., Bruinsma, J., others, 2012. World agriculture towards 2030/2050: the 2012 revision.

457 Asano, T., Cotruvo, J.A., 2004. Groundwater recharge with reclaimed municipal 458 wastewater: Health and regulatory considerations. Water Res. 38, 1941-1951. https://doi.org/10.1016/j.watres.2004.01.023 
460

461

462

463

464

465

466

467

468

469

470

471

472

473

474

475

476

477

478

479

480

481

Barker, Z.A., Stillwell, A.S., Berglund, E.Z., 2016. Scenario analysis of energy and water trade-offs in the expansion of a dual water system. J. Water Resour. Plan. Manag. $142,5016012$.

BOE, 2007. Real Decreto 1620/2007, de 7 diciembre por el que se establece el régimen jurídico de la reutilización de las aguas depuradas. N 294, 50639.

Burek, P., Satoh, Y., Fischer, G., Kahil, M.T., Scherzer, A., Tramberend, S., Nava, L.F., Wada, Y., Eisner, S., Flörke, M., others, 2016. Water futures and solution-fast track initiative.

Cabrera, E., Pardo, M.A., Cabrera Jr., E., Arregui, F.J., 2013. Tap Water Costs and Service Sustainability, a Close Relationship. Water Resour. Manag. 27, 239-253. https://doi.org/10.1007/s11269-012-0181-3

Carr, G., Potter, R.B., Nortcliff, S., 2011. Water reuse for irrigation in Jordan: Perceptions of water quality among farmers. Agric. Water Manag. 98, 847-854. https://doi.org/10.1016/j.agwat.2010.12.011

Chen, W., Bai, Y., Zhang, W., Lyu, S., Jiao, W., 2015. Perceptions of different stakeholders on reclaimed water reuse: The case of Beijing, China. Sustain. https://doi.org/10.3390/su7079696

Chen, W., Lu, S., Jiao, W., Wang, M., Chang, A.C., 2013. Reclaimed water: A safe irrigation $\begin{array}{lllll}\text { water } & \text { source? } & \text { Environ. } & \text { Dev. } & \text { 8, }\end{array}$ https://doi.org/10.1016/j.envdev.2013.04.003

Chhipi-Shrestha, G., Rodriguez, M., Sadiq, R., 2019. Selection of sustainable municipal water reuse applications by multi-stakeholders using game theory. Sci. Total 
Environ. 650, 2512-2526. https://doi.org/10.1016/j.scitotenv.2018.09.359

483 484

485

486

487

488

489

490

491

492

493

494

495

496

497

498

499

500

501

502

503

Cortez, S., Teixeira, P., Oliveira, R., Mota, M., 2008. Rotating biological contactors: A review on main factors affecting performance. Rev. Environ. Sci. Biotechnol. https://doi.org/10.1007/s11157-008-9127-x

Deng, S., Yan, X., Zhu, Q., Liao, C., 2019. The utilization of reclaimed water: Possible risks arising from waterborne contaminants. Environ. Pollut. https://doi.org/10.1016/j.envpol.2019.113020

EU, 2020. REGULATION (EU) 2020/741 OF THE EUROPEAN PARLIAMENT AND OF THE COUNCIL on minimum requirements for water reuse.

Fan, Y., Chen, W., Jiao, W., Chang, A.C., 2015. Cost-benefit analysis of reclaimed wastewater reuses in Beijing. Desalin. Water Treat. https://doi.org/10.1080/19443994.2013.859102

García-Rubio, M.A., Ruiz-Villaverde, A., González-Gómez, F., 2015. Urban water tariffs in Spain: What needs to be done? Water 7, 1456-1479.

Grady Jr, C.P.L., 1982. Modelling of biological fixed films--A state of the art review, in: Proceedings of the 1st International Conference on Fixed-Film Biological Processes, April. pp. 20-23.

Hamilton, A.J., Boland, A.-M., Stevens, D., Kelly, J., Radcliffe, J., Ziehrl, A., Dillon, P., Paulin, B., 2005. Position of the Australian horticultural industry with respect to the use of reclaimed water. Agric. Water Manag. 71, 181-209.

Hong, P.Y., Al-Jassim, N., Ansari, M.I., Mackie, R.I., 2013. Environmental and public health implications of water reuse: Antibiotics, antibiotic resistant bacteria, and antibiotic 
resistance genes. Antibiotics. https://doi.org/10.3390/antibiotics2030367

IEAIE, 2016. Water Energy Nexus; Excerpt from the World Energy Outlook 2016. Paris.

INE, 2018. Suministro y Saneamiento del agua en España [WWW Document]. URL https://www.ine.es/infografias/infografia_suministro_agua.pdf

Jiménez, B., Drechsel, P., Koné, D., Bahri, A., Raschid-Sally, L., Qadir, M., 2010. Wastewater, sludge and excreta use in developing countries: an overview.

Jodar-Abellan, A., Fernández-Aracil, P., Melgarejo-Moreno, J., 2019a. Assessing water shortage through a balance model among transfers, groundwater, desalination, wastewater reuse, and water demands (SE Spain). Water (Switzerland). https://doi.org/10.3390/w11051009

Jodar-Abellan, A., López-Ortiz, M.I., Melgarejo-Moreno, J., 2019b. Wastewater treatment and water reuse in Spain. Current situation and perspectives. Water (Switzerland). https://doi.org/10.3390/w11081551

Kandiah, V.K., Berglund, E.Z., Binder, A.R., 2016. Cellular automata modeling framework for urban water reuse planning and management. J. Water Resour. Plan. Manag. $142,4016054$.

Kang, D., Lansey, K., 2012. Dual water distribution network design under triple-bottomline objectives. J. Water Resour. Plan. Manag. 138, 162-175. https://doi.org/10.1061/(ASCE)WR.1943-5452.0000161

Kleiner, Y., Rajani, B., 2001. Comprehensive review of structural deterioration of water mains: statistical models. Urban water 3, 131-150. 
545

Lee, H., Tan, T.P., 2016. Singapore's experience with reclaimed water: NEWater. Int. J. Water Resour. Dev. 32, 611-621. https://doi.org/10.1080/07900627.2015.1120188

Mas Ortega, J.G., 2016. Análisis coste/beneficio aplicado a los procesos de depuración y reutilización.

Matamoros, V., Rodríguez, Y., Albaigés, J., 2016. A comparative assessment of intensive and extensive wastewater treatment technologies for removing emerging contaminants in small communities. Water Res. 88, 777-785.

Metcalf, Eddy, I., Asano, T., Burton, F.L., Leverenz, H., Tsuchihashi, R., Tchobanoglous, G., 2007. Water reuse. McGraw-Hill Professional Publishing.

Molinos-Senante, M., Hernández-Sancho, F., Sala-Garrido, R., 2011. Cost-benefit analysis of water-reuse projects for environmental purposes: A case study for spanish wastewater treatment plants. J. Environ. Manage. https://doi.org/10.1016/j.jenvman.2011.07.023

Müller, K., Cornel, P., 2017. Setting water quality criteria for agricultural water reuse $\begin{array}{lllll}\text { purposes. } & \text { J. Water } & \text { Reuse }\end{array}$ https://doi.org/10.2166/wrd.2016.194

Nowak, O., 2000. Upgrading of wastewater treatment plants equipped with rotating biological contactors to nitrification and P removal. Water Sci. Technol. 41, 145153.

Olcina Cantos, J., Campos Rosique, A., del Busto, I., Ayanz López-Cuervo, J., Rodr \’\iguez Mateos, M., Mart \’\inez Puentes, M., others, 2018. Resiliencia en el ciclo urbano del 
agua. Extremos pluviométricos y adaptación al cambio climático en el ámbito mediterráneo.

Ortega de Miguel, E., Ferrer Medina, Y., Salas Rodríguez, J.J., Aragón Cruz, C., Real Jiménez, Á., 2010. Manual para la implantación de sistemas de depuración en pequeñas poblaciones. Ministerio Medio Ambiente y Medio Rural y Marino, Madrid.

Pardo, M., Riquelme, A., 2019. A software for considering leakage in water pressurized $\begin{array}{lllll}\text { networks. } & \text { Comput. } & \text { Appl. } & \text { Eng. } & \text { Educ. }\end{array}$ https://doi.org/https://doi.org/10.1002/cae.22110

Pardo, M.A., Valdes-Abellan, J., 2018. Pipe replacement by age only, how misleading could it be? Water Supply 19, 846-854. https://doi.org/10.2166/ws.2018.131

Petousi, I., Fountoulakis, M.S., Stentiford, E.I., Manios, T., 2015. Farmers' Experience, Concerns and Perspectives in Using Reclaimed Water for Irrigation in a Semi-Arid Region of Crete, Greece. Irrig. Drain. 64, 647-654. https://doi.org/10.1002/ird.1936

Ravishankar, C., Nautiyal, S., Seshaiah, M., 2018. Social acceptance for reclaimed water use: a case study in Bengaluru. Recycling 3, 4 .

Rossman, L.A., 2000. EPANET 2: users manual.

Scholz, M., 2006. Sludge treatment and disposal, wetland systems to control urban runoff, 163-174. UK Elsevier Sci. Technol.

Scott, C.A., Faruqui, N.I., Raschid-Sally, L., 2004. Wastewater use in irrigated agriculture: Confronting the livelihood and environmental realities. CABI. 
Sheng, Z., 2005. An aquifer storage and recovery system with reclaimed wastewater to preserve native groundwater resources in El Paso, Texas. J. Environ. Manage. https://doi.org/10.1016/j.jenvman.2004.10.007

Siebert, S., Burke, J., Faures, J.-M., Frenken, K., Hoogeveen, J., Döll, P., Portmann, F.T., 2010. Groundwater use for irrigation--a global inventory. Hydrol. earth Syst. Sci. $14,1863-1880$.

Tang, S.L., Yue, D.P.T., Li, X.Z., 2006. Comparison of engineering costs of raw freshwater, reclaimed water and seawater for toilet flushing in Hong Kong. Water Environ. J. 20, 240-247. https://doi.org/10.1111/j.1747-6593.2006.00036.x

Toze, S., 2006. Reuse of effluent water - Benefits and risks, in: Agricultural Water Management. pp. 147-159. https://doi.org/10.1016/j.agwat.2005.07.010

UN, 2019. World Water Development Report.

UNESCO-WWAP, 2012. Facts and Figures from the United Nations World Water Development Report 4 (WWDR4).

Vergine, P., Lonigro, A., Salerno, C., Rubino, P., Berardi, G., Pollice, A., 2017. Nutrient recovery and crop yield enhancement in irrigation with reclaimed wastewater: a case study. Urban Water J. 14, 325-330.

Voulvoulis, N., 2018. Water reuse from a circular economy perspective and potential risks from an unregulated approach. Curr. Opin. Environ. Sci. Heal. https://doi.org/10.1016/j.coesh.2018.01.005

Wada, Y., Van Beek, L.P.H., Bierkens, M.F.P., 2012. Nonsustainable groundwater sustaining irrigation: A global assessment. Water Resour. Res. 48. 
592 Wang, Z., Li, J., Li, Y., 2017. Using Reclaimed Water for Agricultural and Landscape 593 Irrigation in China: a Review. Irrig. Drain. 66, 672-686. $594 \quad$ https://doi.org/10.1002/ird.2129

595 Winpenny, J., Heinz, I., Koo-Oshima, S., 2010. The Wealth of Waste : The Economics of 596 Wastewater Use in Agriculture. FAO Water Rep. 1-142.

597 


\section{8. LIST OF FIGURES}

600 Figure 1. Flowchart of the calculation process

601

602 Figure 2. The general layout of the network.

603

604

Figure 3. Layout Dual network.

605

606

Figure 4 . Environmental costs $\left(E U R / m^{3}\right)$ variation

607

608

609 


\section{9. LIST OF TABLES}

612

613

614

615

616

617

618

619

620

621

622

623

624

625

626

627

Table 1. Indoor household use.

Table 2. Quality groups according to established bacteriological limits in the R.D. 1620/2007 for each use

Table 3. Typical composition of wastewater effluent.

Table 4. Management and operation costs for an Inhoff tank and an RBC.

Table 5. Water and energy audit results

Table 6. Pollutants concentration of the effluent

Table 7. Environmental cost for different values of - equivalent continuous discount rate-r and payback period. 